\title{
Analysis of the presence and location of mast cells in periapical cysts and periapical granulomas
}

\author{
Análise da presença e localização de mastócitos nos cistos periapicais e granulomas periapicais
}

\author{
Emerson Filipe de Carvalho NOGUEIRA ${ }^{1}$ \\ Elder Gyress Feitosa FARIAS ${ }^{1}$ \\ Luciano Barreto SILVA ${ }^{1}$ \\ Alexandrino Pereira dos SANTOS NETO' \\ Emanuel Sávio de Souza ANDRADE ${ }^{1}$ \\ Gerhilde Callou SAMPAIO'
}

\section{ABSTRACT}

\section{Objective}

The aim of the present study was to locate mast cells in chronic periapical lesions (granulomas and cysts) by using histochemical techniques and toluidine blue staining.

\section{Methods}

A quantitative, descriptive, cross-sectional and retrospective research was performed. The sample was obtained from histopathological reports in the archives of the laboratory of surgical pathology of the University of Pernambuco between November 2014 and May 2015.

\section{Results}

Sixteen cases of granuloma and 21 cases of periapical cysts were selected. The stained slides were analyzed by two examiners at different times, in a double-blind study. Mast cells were found in 13 (61.9\%) of the periapical cyst cases, located in the capsule of the lesion. In the periapical granuloma cases, mast cells were found in eight cases (50\%), located in the granulation tissue.

\section{Conclusion}

Mast cells were detected in both cysts and periapical granuloma, located in the capsule and granulation tissue, respectively. Mast cells were more prevalent in periapical cysts than in periapical granuloma.

Indexing terms: Dental pulp necrosis. Mast cells. Periapical granuloma. Periapical cyst. Toluidine blue.

\section{RESUMO}

\section{Objetivo}

Localizar mastócitos em lesões periapicais (granulomas e cistos) através de técnicas histoquímicas e corante azul de toluidina.

\section{Métodos}

Uma pesquisa quantitativa, descritiva, transversal e retrospectiva foi realizada. As amostras foram obtidas de documentos histopatológicos nos arquivos do laboratório de patologia cirúrgica da Universidade de Pernambuco entre Novembro de 2014 e Março de 2015.

\section{Resultados}

Dezesseis casos de granuloma e 21 casos de cistos periapicales foram selecionados. As lâminas coradas foram analisadas por dois examinadores em tempos diferentes, em um estudo duplo-cego. Mastócitos foram encontrados em $13(61,9 \%)$ dos casos de cistos periapicales, localizados na cápsula da lesão. Nos granulomas periapicais, mastócitos foram encontrados em oito casos (50\%), localizados no tecido de granulação.

\section{Conclusão}

Mastócitos foram detectados tanto em cistos quanto em granulomas periapicais, localizados na cápsula e no tecido de granulação respectivamente. Os mastócitos estavam mais presentes nos cistos do que nos granulomas periapicais.

Termos de indexação: Necrose da polpa dentária. Mastócitos. Granuloma periapical. Cisto radicular. Cloreto de tolônio.

\footnotetext{
${ }^{1}$ Universidade de Pernambuco, Faculdade de Odontologia. Av. General Newton Cavalcanti, 1650, 54756-220, Tabatinga, Camaragibe, PE, Brasil. Correspondência para / Correspondence to: EFC NOGUEIRA. E-mail: <emerson_filipe@hotmail.com>.
} 


\section{INTRODUCTION}

Granulomas and periapical cysts are the most prevalent periapical lesions, and despite the considerable advances in dental research, the rate of failure in endodontic treatment with periapical injuries remains relatively high. It is estimated that only 60 out of every 100 granuloma and/or periapical cysts regress after endodontic treatment, without endodontic surgery'.

The treatment of apical periodontitis consists in the elimination of infection from a root canal and preventing re-infection with the hermetic obturation of the root canal space. Even with all the apparatus and technology available, endodontic treatment many times fails ${ }^{2}$.

The etiopathogenesis of inflammatory periapical injuries is linked to the colonization of microorganisms in the interior of the root canal system. These bacteria liberate intercellular mediators, humoral antibodies and effector molecules for periapical tissues ${ }^{3}$. Such pathological condition may destroy bone and may grow expansively as a consequence of the collapse of the extracellular matrix, leading to the accumulation of osmotic pressure in cystic fluid and/or perilesional bone resorption. The exact mechanism associated with this growth and expansion remains unclear, although it is known that several types of cells, including mast cells, do play a role in such phenomena ${ }^{4}$.

Mast cells are cells that reside in the connective tissue and contain a large number of granules, rich in histamine, heparin, chymase, serotonin, and also cytokines. They are also able to secrete additional mediators, which are not performed by their granules such as interleukins (IL) ${ }^{5}$. Although well known by their significant protective roles in allergies and anaphylaxis, through cross-linking of their surface receptors for $\mathrm{lgE}$; called the human high affinity receptor for IgE $(\mathrm{Fc \varepsilon RI})^{6-7}$ which leads to degranulation and the release of vasoactive, proinflammatory and nociceptive mediators including, IL-6, IL-8, Prostaglandin D2 (PGD2), tryptase, and vascular endothelial growth factor (VEGF) ${ }^{8-}$ 9 , mast cells are also involved in the healing process and defense against pathogens. They are present in most tissues, surrounding the blood vessels, and are prominent in the following areas: close to the skin; in the mucosa of the lungs; in the digestive tract; in the oral cavity; in connective tissue and in the nose ${ }^{10}$. Nevertheless, some studies have found that the presence of mast cells is higher in periapical cysts than in granulomas ${ }^{10,13-14}$. Therefore, locating and quantifying them in the periapical lesions might be an immunohistochemical comparison parameter concerning cysts and granulomas.
Given the importance of mast cells and the functions they perform, the aim of the present study was to locate mast cells in chronic periapical lesions (granulomas and cysts) by using histochemical techniques and toluidine blue staining.

\section{METHODS}

A quantitative, descriptive, cross-sectional and retrospective research was performed. The present study used a convenience sample obtained from histopathological records of granuloma and periapical cysts in the archives from the Surgical Pathology Laboratory in Faculdade de Odontologia de Pernambuco (FOP/UPE) from November 2014 and May 2015. Sixteen cases of periapical granuloma and 21 cases of periapical cysts were analyzed. The samples were selected based on laboratorial previously existing anatomical and pathological records. Nevertheless, all cases were revised by a pathologist in order to ensure greater control of the samples, in previously slides stained with hematoxylin and eosin.

Demographic data (age, gender and race) were obtained from the clinical forms related to biopsy indications in the archives of the above mentioned laboratory.

\section{Toluidine blue staining}

Cuts of $5 \mu \mathrm{m}$ (thickness) were obtained from the material embedded in paraffin. They were then placed on glass slides prior to staining with toluidine blue $(0.2 \%)$. At this stage, cases in which the paraffin blocks did not exhibit sufficient material to obtain semi-serial sections were excluded. Thirty-seven cases were submitted to toluidine blue staining based on the following protocol: xylol for 10 minutes; absolute alcohol for 5 minutes; 80\% alcohol for 5 minutes; $70 \%$ alcohol for 5 minutes; distilled water for 5 minutes; toluidine blue solution for 3 minutes; running water for 8 minutes; drying in a stove at $37^{\circ} \mathrm{C}$ for 24 hours; immersion in xylol for mounting; and mounting in permount.

\section{Microscopic analysis}

The slides were examined under light microscopy (Olympus CH30 RF200), at a magnification of 100 and $400 \mathrm{x}$, to confirm the presence or absence of mast cells in the periapical cysts and periapical granuloma. The staining of mast cells was noted as violet-colored cytoplasmic granules. Slides that exhibited coloration linked to the toluidine blue were analyzed by two examiners at distinct times (triple-blind study). 


\section{Statistical analysis}

In order to determine the degree of coincidence between the examiners, Kappa coincidence scores (descriptive statistics), as well as a confidence interval of 95\% for the population Kappa (inferential statistics), were obtained. The following scale has been suggested for the interpretation of Kappa scores: $<0.20=$ poor; $0.21-0.40=$ weak; $0.41-0.60=$ moderate; $0.61-0.80=$ good; $0.81-0.99$ $=$ excellent; $1.00=$ perfect. Using the confidence interval for this index, it is possible to confirm the hypothesis related to the value of the population Kappa (inferential statistics). The level of significance used in the statistical tests was $5 \%$.

\section{RESULTS}

The age of the patients analyzed ranged from 18 to 69 years, with a mean age of 38.53 years, a median of 37.50 years, a standard deviation of 13.41 years and a coefficient of variation of $34.80 \%$. Age data were available for 32 patients and from these, 18 (56.2\%) were aged between 18 and 40 years and 14 (43.8\%) were aged 41 years or more. Fourteen (37.8\%) of the individuals assessed were male and 23 (62.2\%) were female. Race data were available for 23 of those analyzed. From these, seven $(30.4 \%)$ were black, $14(60.9 \%)$ were white and two $(8.7 \%)$ were classified as other (non-defined color).

From the 37 slides analyzed, corresponding to 37 patients, 21 (56.8\%) corresponded to periapical cyst and $16(43.2 \%)$ to periapical granuloma, as per the established histopathological diagnosis.

The clinical diagnosis of the periapical cyst, provided by the dental surgeon, coincided with the histopathological record in 17 (45.9\%) of the cases. For periapical granuloma, this coincidence was only applicable in three $(8.1 \%)$ of the cases (Table 1$)$.

Table 1. Assessment of the coincidence between the clinical and histopathological diagnoses.

\begin{tabular}{|c|c|c|c|c|c|c|}
\hline \multirow{3}{*}{ Clinical diagnosis } & \multicolumn{4}{|c|}{ Histopathological diagnosis } & & \\
\hline & \multicolumn{2}{|c|}{ Cyst } & \multicolumn{2}{|c|}{ Granuloma } & \multicolumn{2}{|c|}{ Total } \\
\hline & $\mathbf{n}$ & $\%$ & $\mathbf{n}$ & $\%$ & $\mathbf{n}$ & $\%$ \\
\hline Periapical cyst & 17 & 45,9 & 11 & 29,7 & 28 & 75,7 \\
\hline Periapical granuloma & 1 & 2,7 & 3 & 8,1 & 4 & 10,8 \\
\hline Periapical cyst/periapical granuloma & 2 & 5,4 & 2 & 5,4 & 4 & 10,8 \\
\hline Diagnosis not provided by the dental surgeon & 1 & 2,7 & - & - & 1 & 2,7 \\
\hline TOTAL & 21 & 56,8 & 16 & 43,2 & 37 & 100,0 \\
\hline
\end{tabular}

In the 13 cases involving periapical cysts and the presence of mast cells, the cells were located in the lesion capsule. In the eight cases involving periapical granuloma and the presence of mast cells, these cells were located in the granulation tissue (Figure 1 and Table 2).

In the 37 cases involving periapical lesions, coincidence between the examiners, in terms of the detection or not of mast cells, occurred in $29(78,4 \%)$ (moderate Kappa value of 0.56 ). It is important to stress out of the 29 cases of coincidence between the two examiners, $15(51.7 \%)$ were related to the presence of mast cells and 14 (48.3\%) were related to the absence of the mentioned cells.

Table 2. Assessment of the coincidence between the clinical and histopathological diagnoses.

\begin{tabular}{lccrc}
\hline Examiner & \multicolumn{2}{c}{ Coincidence } & Kappa & Cl (95\%) \\
\cline { 2 - 5 } & $\mathbf{n}$ & $\%$ & & \\
\hline E1 x E2 & 29 & 78,4 & 0,56 & 0,30 a 0,85 \\
\hline
\end{tabular}

\section{DISCUSSION}

Considering that mast cells are not easily recognized by hematoxylin and eosin, and may be confused with a variety of other cells and immature granulocytes ${ }^{4}$, the authors of the present study chose to assess these cells through toluidine blue staining. Since toluidine blue is a cationic dye, it exhibits the capacity to selectively integrate with the glycosaminoglycan-protein complex (highly ionized) ${ }^{11}$. A hallmark feature of mast cells from all species is their striking metachromatic staining with various cationic dyes such as toluidine. In these cases, metachromasia occurs as a resultof the absorption spectrum of the dye.

According to Rodini et al. ${ }^{12}$, studies comparing the presence of mast cells in periapical granuloma and periapical cysts have confirmed that the quantity of mast cells is higher in periapical cysts than in granulomas. Mahita et al. ${ }^{10}$ analyzed histologically fifteen periapical 
cysts and fifteen periapical granulomas by using toluidine blue and also found more mast cells in the cysts. The same authors reported that in both lesions, mast cells were more common in the sub-epithelial tissue than in the deep connective tissue. Similar results were found by Patidar et al. ${ }^{13}$ who investigated the presence and distribution of mast cells in periapical cysts, dentigerous cysts and keratocystic odontogenic tumor. Ten cases of each injury were selected. A greater number of mast cells was located in the periapical cysts, in which the sub-epithelial zone contained more mast cells than in deeper zones. Similar results were found in this study, since the presence of mast cells was more significant in periapical cysts than in granulomas. These data could explain the higher growth trends of cysts, since these cells reportedly play an important role in the development of the lesion ${ }^{14-15}$, mainly because the increase in the average mast cell count in cysts may lead to inflammatory changes by the intense release of their chemical mediators; and when stimulated by etiological factors such as bacterial neurotoxins, they increase in number and undergo degranulation, causing inflammatory and vascular changes, contributing to their development and expansion, more than they do in granulomas ${ }^{16}$.

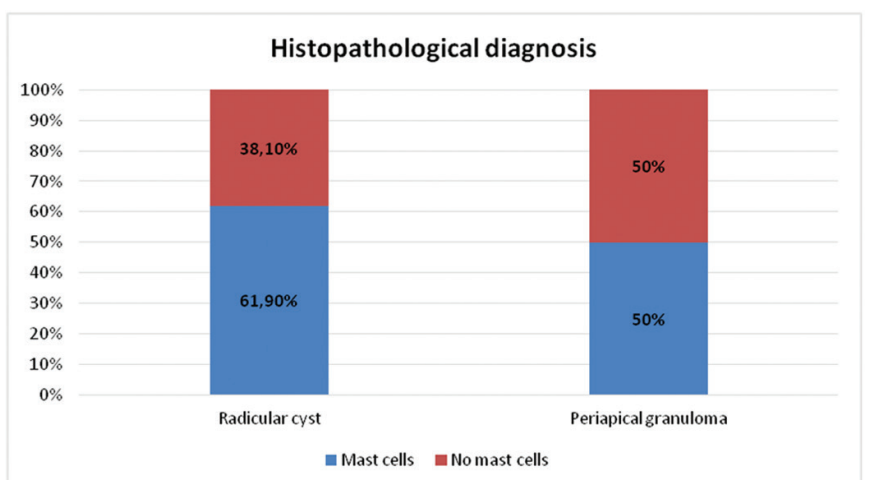

Figure 1. Assessment of the occurrence of mast cells according to the type of histopathological diagnosis.

According to Shafer et al. ${ }^{16}$ and Lindhe ${ }^{17}$, periapical cysts originates from a periapical granulomas with preexisting epithelium, which is a focus of a chronically inflamed intraosseous granulation tissue, located in the apex of a tooth without vitality. Therefore, the periapical cysts are expected to be older and potentially larger than granulomas, which might explain the greater amount of mast cells in the former.
Mast cell proteases, classified into a carboxypeptidase, chymases, and tryptases $^{18}$, also cleaves and inactivates interleukins, such as IL-6,IL-13, TNF, Endothelin ${ }^{1}$ and Anaphylatoxin C3a. This can only be described as an anti-inflammatory action which restrains the excess inflammation. They also promote neutrophil and eosinophil aggregation, while stimulate $T$ lymphocyte and influence the endothelial cells to release mediators upon activation, contributing during process of repair by neo-angiogenesis, fibrinogenesis and reepithelization, characterizing a pro inflammatory action as well ${ }^{20}$. Therefore, depending on the situation, mast cells can stimulate inflammation or restrain it, influencing the acutization and chronification processes.

In this study, all of the stained mast cells were detected in the capsule of periapical cysts, similar to the study of Mahita et al. ${ }^{10}$ accomplished in 2015. The authors stated that the constituents of the periapical capsule included mast cells, among other cell types. This specific location could emphasize the findings reported in 1996, concerning bone resorption, in the work of Teronen et al. ${ }^{20}$. These authors stated that mast cells, typically those belonging to the degranulated variety, were located in the periphery of odontogenic cysts and used the secretion of tryptase to contribute to bone resorption during the growth of cysts.

Concerning the location of mast cells in periapical cysts, it was notable that, even in confirmed cases of exocytosis, no mast cells were observed permeating the epithelium of cysts. This finding corroborates Norrby ${ }^{21}$ and Metz et al. ${ }^{22}$, both of whom previously stated that mast cells are usually located in the connective tissue of mammals, with the exception of avascular tissue, such as the epithelium. However, the studies of Mahita et al. ${ }^{10}$ Rodini et al. ${ }^{12}$ and Patidar et al. ${ }^{13}$ disagreed with these statements as they all detected mast cells in the epithelium in connective tissue, as well as in intra-epithelial areas. Similar to the studies mentioned above, the quantity of mast cells found in the present study was low, which may have been due to the condition of the paraffin blocks and the consequent loss of reactivity to the dye, which may happen as a result of time effect which many decrease the reactivity, but not so much as to contraindicate the method.

In periapical granulomas, mast cells were found permeating the granulation tissue. These findings are in agreement with the results of Perrini and Fonzi ${ }^{23}$, which confirmed the presence of mast cells in periapical granulomas. These authors did not use quantification methods in their 
research, similar to the present study. However, the study of Kontianen et al. ${ }^{24}$ reported that $2 \%$ of the cells in granuloma and periapical cysts were mast cells.

Mast cells were detected in the thick connective tissue (capsule) of cysts in the present study.This finding can be explained by the conclusions of Ruoss et al. ${ }^{25}$ which stated that mast cells are necessary for pathological responses and suggested that they play an important role in fibroblastic proliferation. Torabinejad and Bakland ${ }^{16}$, in 1978, already proposed that the reaction measured by IgE could play a significant role in the initiation and development of periapical lesions if mast cells and effector $B$ cells containing IgE were present.

Santos Netto et al. ${ }^{4}$ analyzed mast cells using the toluidine blue technique and an immunohistochemical technique involving anti-tryptase antibody (clone G3) with 20 periapical cysts, 20 dentigerous cysts (14 inflamed and six non-inflamed) and 20 keratocystic odontogenic tumors. They noted that the mean number of mast cells found using the immunohistochemical technique was higher than when using histochemistry $(P<0.0001)$. They also found a greater quantity of mast cells in inflamed dentigerous cysts and keratocystic odontogenic tumors than in noninflamed lesions, which could indicate the participation of these cells in the inflammatory responses associated with odontogenic injuries.

From the 29 cases that were coincident among the two examiners in the present study, 15 (51.7\%) were correlated with the presence of mast cells and 14 $(48.3 \%)$ were correlated with the absence of mast cells (moderate Kappa value of 0.56 ). This value is notable, given that the histological analysis of the detection of cells remains subjective.

Based on the concept that mast cells play a critical role in the induction of inflammation, therapeutic agents

\section{REFERENCES}

1. Leonardo MR. Endodontia: tratamento de canais periapicales: princípios técnicos e biológicos. São Paulo: Artes Médicas; 2005.

2. Nair PNR. Pathogenesis of apical periodontitis and the causes of endodontic failures. Crit Rev Oral Biol Med. 2004;15(6):348-81. doi: $10.1177 / 154411130401500604$

3. Bornstein MM, Bingisser AC, Reichart PA, Sendi P, Bosshardt DD; Von Arx T. (2015). Comparison between Radiographic (2-dimensional and 3-dimensional) and Histologic Findings of Periapical Lesions Treated with Apical Surgery. J Endod. 2015 Jun;41(6):804-11. doi: 10.1016/j.joen.2015.01.015 should be used to alter their function and secretion, in order to impede inflammation in its early stages. These findings suggest the possible role of mast cells in the pathogenesis of periapical lesions ${ }^{10}$.

One of the limitations of the present study was the lack of quantification by field for the mast cells located in the lesions studied, which would have made this research more complete and interesting. Therefore, we suggest that future studies include such method, as well as the detection of other cells and proteins, using other dyes and immunohistochemical techniques for mast cells. Metalloproteinases are markers of mast cells and would certainly provide a more satisfactory elucidation of these endodontic pathogens.

\section{CONCLUSION}

Despite the fact that mast cells were found in both of the periapical lesions, their occurrence was greater in periapical cysts, particularly in the capsule. This could explain the greater growth potential observed in the periapical cysts than in the periapical granulomas.

\section{Collaborators}

EFC NOGUEIRA and EGF FARIAS participated in the data collection; LB SILVA, EGF FARIAS ESS ANDRADE and performed the literature review and writing the manuscript in English. ES Souza ANDRADE and GC SAMPAIO supervised all stages of research. All authors reviewed the text and approved its final version.

4. Santos Netto JN, Pires FR, Da Fonseca EC, Silva LE, Lourenço SQC. Evaluation of mast cells in periapical cysts, dentigerous cysts, and keratocystic odontogenic tumors. J Oral Pathol Med. 2012 Sep;41(8):630-6. doi: 10.1111/j.1600-0714.2012.01126.x

5. Rama T, Côrte-Real I, Gomes PS. Mastocytosis: oral implication of rare disease. J Oral Pathol Med. 2011 Jul;40(6):441-50. doi: 10.1111/j.1600-0714.2010.00996.x

6. Blank U, Rivera J. The ins and outs of IgE-dependent mast- cell exocytosis. Trends Immunol. 2004;25:266-273. doi: 10.1016/j. it.2004.03.005

7. Kraft S, Rana S, Jouvin MH, Kinet JP. The role of the FC冈RI \-chain in allergic diseases. Int. Arch. Allergy Immunol. 2004;135:62-72. 
8. Grützkau A, Krüger-Krasagakes $S$, Baumeister H, Schwarz C, Kögel $\mathrm{H}$, Welker $\mathrm{P}$, et al. Synthesis, storage, and release of vascular endothelial growth factor/vascular permeability factor (VEGFNPF) by human mast cells: implications for the biological significance of VEGF206. Mol Biol Cell. 1998 Apr;9(4):875-84.

9. Galli SJ, Nakae S, Tsai M. Mast cells in the development of adaptive immune responses. Nat Immunol. 2005;6:135-142. doi:10.1038/ ni1158

10. Mahita VN, Manjunatha BS, Shah R, Astekar M, Purohit S, Kovvuru S. (2015).Quantification and localization of mast cells in periapical lesions. In: Culling CFA. Allison RT, Barr WT. Cellular pathology technique. 4th. ed. London: Butterworths; 1985. p. 642.

11. Rönnberg E, Melo FR, Pejler G. Mast cell proteoglycans. J Histochem Cytochem. 2012 Dec;60(12):950-62. doi: $10.1369 / 0022155412458927$

12. Rodini CO, Batista AC, Lara VS. Comparative immunohistochemical study of the presence of mast cells in apical granulomas and periapical cysts: Possible role of mast cells in the course of human periapical lesions. Oral Surg Oral Med Oral Pathol Oral Radiol Endod. 2004;97(1):59-63. doi: 10.1016/S1079-2104(03)00378-0

13. Patidar KA, Parwani RN, Wanjari SP, Patidar AP. Mast cells in human odontogenic cysts. Biotech Histochem. 2012 Aug;87(6):397-402. doi: 10.3109/10520295.2012.674556

14. Ledesma-Montes C, Garcés-Ortíz M, Rosales-García G, Hernández-Guerrero JC. Importance of mast cells in human periapical inflammatory lesions. J Endod. 2004 Dec;30(12):855-9.

15. Reet Kamal, ParveenDahiya. Comparative analysis of mast cell count in normal oral mucosa and oral pyogenic granuloma. J Clin Exp Dent. 2011;3(1):e1-4.

16. Shafer WG, Hine MK, Levy BM. Tratado de patologia bucal. $4^{\mathrm{a}}$ ed. Rio de Janeiro: Guanabara Koogan; 1987.

17. Lindhe J, Karring T, Lang NP. Tratado de periodontia clínica e implantologia oral. $3^{a}$ ed. Rio de Janeiro: Guanabara Koogan; 1999.
18. Huang C, Sali A, Stevens RL. Regulation and function of mast cell proteases in inflammation. J Clin Immunol. 1998 May;18(3):16983.

19. Artuc M, Hermes B, Steckelings UM, Grützkau A, Henz BM. Mast cells and their mediators in cutaneous wound healing-active participants or innocent bystanders? Exp Dermatol. 1999 Feb;8(1):1-16.

20. Teronen O, Hietanen J, Lindqvist C, Salo T, Sorsa T, Eklund KK, et al. Mast cell-derived tryptase in odontogenic cysts. J Oral Pathol Med. 1996 Aug;25(7):376-81.

21. Norrby K. Mast cells and angiogenesis. APMIS. 2002 May;110(5):355-71.

22. Metz M, Grimbaldeston MA, Nakae S, Piliponsky AM, Tsai M, Galli SJ. Mast cells in the promotion and limitation of chronic inflammation. Immunol Rev. 2007 Jun;217:304-28.

23. Perrini N, Fonzi L. Mast cells in human periapical lesions: ultrastructural aspects and their possible physiopathological implications. J Endod. 1985 May;11(5):197-202. doi: 10.1016/ S0099-2399(85)80060-1

24. Kontiainen S, Ranta H, Lautenschlager I. Cells infiltrating human periapical inflammatory lesions. J Oral Pathol. 1986 Nov; 15(10):544-6.

25. Ruoss SJ, Hartmann T, Caughey GH. Mast cell tryptase is a mitogen for cultured fibroblasts. J Clin Invest. 1991 Aug;88(2):493-9. 